\title{
Impact of Abattoir Effluents on the pH, Organic Matter, Heavy Metal Levels and Microbial Composition of Surrounding Soils in Calabar Municipality
}

\author{
V. F. Ediene ${ }^{1^{*}}$ and O.B. Iren ${ }^{1}$ \\ ${ }^{1}$ Department of Soil Science, University of Calabar, Calabar, Nigeria.
}

Authors' contributions

This work was carried out in collaboration between both authors. Author VFE designed the study and managed the analyses of the study and did the statistical analysis Author OBI wrote the first draft of the manuscript and managed the literature searches. Both authors read and approved the final manuscript.

Article Information

DOI: $10.9734 / A J E E / 2017 / 33341$

Editor(s):

(1) Adamczyk Bartosz, Department of Food and Environmental Sciences, University of Helsinki, Finland.

Reviewers:

(1) Mustapha Umar, Nigerian Institute of Leather and Science Technology, Nigeria.

(2) Onisogen Edori, Ignatius University of Education Rumuolumeni, Nigeria.

(3) Prakash M Munnoli, SDM College of Engineering and Technology, Dharwad, India. Complete Peer review History: http://www.sciencedomain.org/review-history/19111

Original Research Article

Received 11 $1^{\text {th }}$ April 2017

Accepted $10^{\text {th }}$ May 2017

Published $18^{\text {th }}$ May 2017

\section{ABSTRACT}

This study examined the impact of abattoir activities on the heavy metal levels and microbial composition in surrounding soils receiving abattoir effluents within Calabar Metropolis. A total of nine composite soil samples were gotten from three locations: Atimbo, Ikot Eneobong and Nasarawa abattoir and environs. The results obtained revealed that the uncontaminated sites (control) had a strongly acidic $\mathrm{pH}$ while the abattoir contaminated soils were slightly acidic to slightly alkaline in reaction. Soil organic carbon content was low $(<1.5 \%)$ at the control site while the abattoir contaminated sites were high (>2.0\%). The heavy metal levels were highest at the point of direct discharge of abattoir effluents (Cu: $7.27 \mathrm{mg} / \mathrm{Kg}$; Cd: $0.49 \mathrm{mg} / \mathrm{Kg} ; \mathrm{Zn}: 47.23 \mathrm{mg} / \mathrm{Kg} ; \mathrm{Pb}: 2.62 \mathrm{mg} / \mathrm{Kg}$ and Fe: $1071.69 \mathrm{mg} / \mathrm{Kg}$ ) followed by the surrounding soils (Cu: $6.60 \mathrm{mg} / \mathrm{Kg} ; \mathrm{Cd}: 0.40 \mathrm{mg} / \mathrm{Kg} ; \mathrm{Zn}$ : $30.86 \mathrm{mg} / \mathrm{Kg} ; \mathrm{Pb}: 1.81 \mathrm{mg} / \mathrm{Kg}$ and $\mathrm{Fe}: 871.76 \mathrm{mg} / \mathrm{Kg}$ ) and the least values were obtained from the 
control (Cu: $5.45 \mathrm{mg} / \mathrm{Kg}$; Cd: $0.30 \mathrm{mg} / \mathrm{Kg} ; \mathrm{Zn}: 16.30 \mathrm{mg} / \mathrm{Kg} ; \mathrm{Pb}: 1.60 \mathrm{mg} / \mathrm{Kg}$ and $\mathrm{Fe} 586.25 \mathrm{mg} / \mathrm{Kg}$ ). Bacterial communities such as: Escherichia coli, Bacillus spp, Staphylococcus spp, Klebsiella pneumoniae and Staphycoccus epidermis were isolated from the abattoir effluents contaminated sites. Fungal isolates from the abattoir effluents contaminated soils include: Aspergillus spp, Fusarium sporotrichiodes, Penicillium erichimultum, Absidia spp. and Mucor pusillus. Generally, bacteria and fungi population and diversity were higher in abattoir effluents contaminated soils than the control. The increase in heavy metals levels and the presence of numerous and diverse communities of organisms indicated possible pollution. This calls for concern, as increase levels of heavy metals and invading pathogenic organisms can pollute water bodies as well as affect plant, human and animal health. Therefore, abattoir effluents should be channeled into septic tanks where it can be properly treated before being discharged into the soil environment.

Keywords: Abattoir effluents; heavy metals; microbial composition; soil properties.

\section{INTRODUCTION}

An abattoir is an approved place where animals are killed and processed for their meat and skin. Abattoir generates large effluents and waste water. The effluents is complex in composition and can alter the chemical composition of the receiving soils [1] which may be harmful to the environment at large.

Various products of livestock have been found to contain heavy metals. Feed materials grown on polluted soils, or treated with mineral and organic fertilizers, direct urination and defecation by animals, pesticides, soil amendment (liming and gypsum application), drinking water, and pharmaceutical etc. account for the major route of heavy metal uptake by livestock. Other sources are accidental access to limed field, mineral supplements with high content of trace metal and licking of soil and painted surfaced containing metallic pigments [2].

Indiscriminate discharges of abattoir effluents into soils have been reported to accumulate metals in receiving soils [3]. Contamination of agricultural land by heavy metals is of critical environmental concern due to their potential adverse ecological effects and undesirable changes in the environment with hazardous consequences. Soil organisms, on the other hand, do not readily adapt to or degrade heavy metals because metals slow down the speed of growth, activities and reproduction of functional microbial population in the soil thus prevailing slower growing organisms with lower diversity and higher resistance to heavy metals, but decreased biological activity $[4,5]$. Concerns about heavy metals in soils are not just limited to their toxicity to living organisms inhabiting the soil but also because failure to alleviate heavy metal build-up and persistence in soil may result in immobilization within different organic and inorganic colloids and mobilization into the flora and fauna and subsequently become available in food chain with deleterious health effects $[6,7]$. When these metals accumulate in plant tissues, animals grazing on such contaminated plants and drinking from polluted water also accumulate such metals in their tissues and milk if lactating [8-11]. These metals are ultimately released back to the through the blood, milk, urine faeces, paunch material and other animal parts when slaughtered culminating in a vicious cycle.

Soil pollution as a result of improper disposal of abattoir effluents and waste in Calabar Metropolis is on the increase, with the last decades witnessing greater quantities of these effluents in soil. This research therefore aims at assessing the impact of abattoir effluents on soil chemical properties, levels of heavy metals and microbial composition in surrounding soils receiving abattoir effluents in Calabar.

\section{MATERIALS AND METHODS}

\subsection{Description of the Study Area}

The study area is located in Calabar Municipality. Calabar Municipality lies between latitude $04^{\circ}$ $15^{\prime \prime}$ and $05^{\circ} 05^{\prime \prime} \mathrm{N}$ and longitude $08^{\circ} 15^{\prime \prime}$ and $08^{\circ}$ 25 " E in southern Cross River State, South-South Nigeria. Calabar municipality is bordered by Odukpani LGA in the North, the great Kwa River in the North-East and Akpabouyo LGA in the West. Its Southern shores are bounded by the Calabar River and Calabar South Local Government Area respectively. The area is characterized by tropical climate, distinct rainy and dry seasons, with an annual rainfall of 2360 $\mathrm{mm}$ (ranging from 2290 to $2680 \mathrm{~mm}$ ), annual temperature range of $21-31^{\circ} \mathrm{C}$ and relative humidity of 82 to $89 \%$ [12]. The vegetation is 
mainly humid tropical vegetation with vegetables such as Telferia occidentalis, Talinum triangulare, Abelmoschus esculentus and crops such as Zea maize, and Manihot esculenta grown by farmers. Soils in Calabar are mostly sandy and low in nutrients [13]. The area is characterized by many rivers and streams.

\subsection{Field Studies}

Representative composite soil samples were collected at depth of $0-30 \mathrm{~cm}$ using soil auger from Atimbo, Ikot Eneobong and Nasarawa abattoirs and its environs in Calabar municipality. Three sampling points were mapped out around each abattoir location [14]. Point (1) was the point of direct discharge of the effluents from the abattoir into the soil and served as the reference point. Point (2) was $20 \mathrm{~m}$ from point (1) but still within the effluents site. Point 3 was $100 \mathrm{~m}$ from point (1) and served as the control. Three composite samples were collected from each abattoir location bringing the total number of samples to nine (9). Soil samples for microbial analyses were collected aseptically in sterile polythene bags, labelled and transported in ice parked coolers to the laboratory for analysis [15].

\subsection{Heavy Metal Analyses}

Soil samples from the study sites were collected and air dried. Two replicates of $2.5 \mathrm{~g}$ sediments were acid-digested in microwave assisted Kjeldahl digester. To each microwave extraction vessel was added with $5 \mathrm{ml}$ of concentrated nitric acid, $2 \mathrm{ml}$ hydrochloride acid and $1 \mathrm{ml}$ of hydrofluoric acid. The vessels were capped and heated in a microwave unit at $800 \mathrm{~W}$ to a temperature of $210^{\circ} \mathrm{C}$ for 20 min with pressure of 40 bar. The digested samples were analyzed for heavy metals by atomic absorption spectrophotometer using flame atomization [16].

\subsection{Microbial Analyses}

Reagents used in the study: Soil Extract was prepared by suspending $1000 \mathrm{~g}$ of soil in 1 litre $(1000 \mathrm{ml})$ of distilled water and stirred vigorously using stirring rod. The mixture was filtered with a Whatman No. 4 filter paper. The filtrate was sterilized by autoclaving at a temperature of $121^{\circ} \mathrm{C}$ and pressure of $1 \mathrm{~b} / \mathrm{sq}$. inch for 15 minutes. The extract was used in the preparation of agar for the estimation of total heterotrophic aerobic bacteria, purification and for stock culture. Malt extract agar was used for the isolation of fungi [17]

\subsection{Enumeration of Total Heterotrophic Bacteria and Fungi}

Soil samples were serially diluted in ten folds [17]; Dilution factors of $10^{-6}$ and $10^{-3}$ were used for bacteria and fungi cultures respectively. Total viable heterotrophic aerobic bacterial and fungal counts were determined using the pour plate technique. Molten soil extract agar and malt extract agar were poured into sterile Petri-dishes containing $1 \mathrm{ml}$ of the appropriate aliquot diluents for the isolation of total heterotrophic bacteria and fungi, however, plating was done in triplicates while observing all precautions. Colony count was taken after incubating the plates at $30^{\circ} \mathrm{C}$ for 24 and 48 hours for bacteria and fungi respectively. The bacterial and fungal isolates were sub cultured into nutrient agar slants which were then used for biochemical tests $[17,18]$.

\subsection{Characterization and Identification of Isolates}

Characterization and identification was carried out at a magnification of X40 using an objective lens. Gram positive (+ve) organisms were seen as blue or violet colourations while red colours indicate gram negative (-ve) bacteria, however, spore formation, motility, oxidase and catalase production; Citrate utilization, oxidative /fermentation (O/F) utilization of glucose; indole and coagulase production, starch hydrolysis, sugar fermentation, methyl red, Voges Proskaur reaction and urease production tests were also performed following standard procedures [15-21]. Microbial identification was performed as outlined in [22]. Fungal isolates were examined macroscopically and microscopically using the needle mounts technique $[18,23]$.

\section{RESULTS AND DISCUSSION}

\subsection{Physicochemical Properties and Heavy Metal Levels}

The results of the means of the physicochemical properties and heavy metals levels of soils contaminated with abattoir effluents in Atimbo, Ikot Eneobong and Nasarawa are presented in Table 1. The result indicated that particle size distribution was dominated by sand (Table 1), with values ranging from $87-88 \%, 87-88 \%$ and $82-87 \%$ for Points 3, 1 and 2 respectively. 
Silt fraction was $11.00 \%$ at the control site, 11$12 \%$ at Point 1 and $12-17 \%$ at Point 2. Clay was less than $2 \%$ across the entire study sites (Table 1). The soils were mainly loamy sand, indicating that the abattoir effluents had no effect on the textural class. Such sand dominated soils will allow for high rate of leaching and infiltration of the effluents through the soil fractions probably down to the water aquifer.

The soils $\mathrm{pH}$ values ranged between 4.8 - 5.2, $6.3-7.3$ and $6.4-7.35$ with means of $5.00,6.78$ and 6.87 for the Control, Points 1 and 2 respectively.

The soils of the control site were strongly acidic while the abattoir contaminated soils were slightly acidic to slightly alkaline (Table 1 ). Such $\mathrm{pH}$ conditions as observed for the abattoir sites will favour the proliferation of soil microbes as well as the growth of various crops.

Soil organic carbon content was low $(<1.5 \%)$ at the control site (Point 3) with mean value of $1.00 \%$ while values recorded for the abattoir contaminated sites were high (> 2.0\%) with values ranging between $7.00-8.00 \%$ and $6.00-$ $7.00 \%$ for Points 1 and 2 respectively. The high organic carbon content in the abattoir effluents contaminated sites suggests high organic matter content.

Various products of livestock have been reported to contain heavy metals [2]. Leaving us to hypothesize that the effluents will invariably contain heavy metals. Assessing the heavy metals status of the study area is of great concern as a lot of vegetables are cultivated within these sites. Although some metals are considered as micro nutrients and required in minute quantities for plant uptake, nevertheless, excess of these metals can lead to plant and eco-toxicity [24]. Copper (Cu) for instance is considered micronutrient in plant nutrition. Despite the essential nature of $\mathrm{Cu}$, excess of it in soil plays a cytotoxic role, induces stress, retards growth and causes leaf chlorosis and injury to plants [25]. Results obtained from the study site for $\mathrm{Cu}$ ranged between $5.38-5.54 \mathrm{mg} / \mathrm{Kg}, 6.95$ $-7.60 \mathrm{mg} / \mathrm{Kg}$ and $6.20-6.95 \mathrm{mg} / \mathrm{Kg}$ with means of $5.45 \mathrm{mg} / \mathrm{Kg}, 7.27 \mathrm{mg} / \mathrm{Kg}$ and $6.60 \mathrm{mg} / \mathrm{Kg}$ for Points 3,1 and 2 respectively (Table 1 ). Nasarawa recorded the highest value $(7.60$ $\mathrm{mg} / \mathrm{Kg}$ ) (Fig. 3) for $\mathrm{Cu}$ while the point of direct discharge of the abattoir effluents (Point 1) recorded the highest mean $(7.27 \mathrm{mg} / \mathrm{Kg})$. The data obtained for $\mathrm{Cu}$ from the sampling points differed from each other with a standard deviation (SD) of \pm 0.83 with a coefficient variability of $13.00 \%$ suggesting the closeness of the results of the contaminated sites to the control.

Values recorded for $\mathrm{Cu}$ were within the range of $2-100 \mathrm{mg} / \mathrm{Kg}$ recommended by [26] and 2- 250 $\mathrm{mg} / \mathrm{Kg}$ given by [27] as normal range in soil.

Cadmium (Cd), had values ranging between 0.24 $-0.36 \mathrm{mg} / \mathrm{Kg}, 0.45-0.57 \mathrm{mg} / \mathrm{Kg}$ and $0.25-0.55$ $\mathrm{mg} / \mathrm{Kg}$ with means of $0.30 \mathrm{mg} / \mathrm{Kg}, 0.49 \mathrm{mg} / \mathrm{Kg}$ and $0.40 \mathrm{mg} / \mathrm{Kg}$ for Points 3, 1 and 2 respectively with a percentage deviation of $31.00 \%$. The values recorded for $\mathrm{Cd}$ at the abattoir sites in Calabar were however, lower than the 13.21 $30.02 \mathrm{mg} / \mathrm{Kg}$ reported by [3] for abattoir environs in Sokoto and below the $1.1 \mathrm{mg} / \mathrm{Kg}$ (maximum) standard for the regulatory limit of $\mathrm{Cd}$ in agricultural soils $[28,29]$.

Zinc $(\mathrm{Zn})$ is another metal of concern because high levels of $\mathrm{Zn}$ in soil inhibit many plant metabolic functions and limits the growth of both root and shoot [28-31]. The mean analytical determination for $\mathrm{Zn}$ from the study sites ranged from $15.80-17.0 \mathrm{mg} / \mathrm{Kg}, 44.30-52.25 \mathrm{mg} / \mathrm{Kg}$ and $24.30-43.15 \mathrm{mg} / \mathrm{Kg}$ with means of 16.3 $\mathrm{mg} / \mathrm{Kg}, 47.23 \mathrm{mg} / \mathrm{Kg}$ and $30.86 \mathrm{mg} / \mathrm{Kg}( \pm 30.86)$ for locations 3, 1 and 2 concurrently. The least content of $\mathrm{Zn}$ was recorded for the control site while the highest value was recorded at the point of direct discharge of the abattoir effluents into the soil (Table 1). The mean values for $\mathrm{Zn}$ from the study site varied with a CV of $46.00 \%$, indicating a wide spread of the data with each other. The values obtained for $\mathrm{Zn}$ in this research were lower than $56.31-92.50 \mathrm{mg} / \mathrm{Kg}$ recorded by [3] for abattoir effluents contaminated soils in Sokoto and were within permissible limits of 10$300 \mathrm{mg} / \mathrm{Kg}$ recommended by [26] but however, higher than the $5 \mathrm{mg} / \mathrm{Kg}$ quantity required as micronutrient level.

Lead $(\mathrm{Pb})$ from the study sites had values ranging from $1.53-1.64 \mathrm{mg} / \mathrm{Kg}, 2.35-2.95 \mathrm{mg} / \mathrm{Kg}$ and $1.35-2.15 \mathrm{mg} / \mathrm{Kg}$ with means of $1.60 \mathrm{mg} / \mathrm{Kg}$, $2.62 \mathrm{mg} / \mathrm{Kg}$ and $1.81 \pm 0.36 \mathrm{mg} / \mathrm{Kg}$ for the control, Points 1 and 2 correspondingly. The values recorded for $\mathrm{Pb}$ from the study sites were within the recommended soil range $(2-200 \mathrm{mg} / \mathrm{Kg})$ for uncontaminated soils as recorded by [26]. High level of $\mathrm{Pb}$ could inhibit enzymatic activities, alter water imbalance, membrane permeability and disturbs mineral nutrition [32]. 
Ediene and Iren; AJEE, 2(3): 1-10, 2017; Article no.AJEE.33341

Table 1. Mean physicochemical properties and heavy metals $(\mathrm{mg} / \mathrm{Kg})$ in soils contaminated with abattoir effluents in Calabar Metropolis

\begin{tabular}{|c|c|c|c|c|c|c|c|c|c|c|c|}
\hline Location & $\begin{array}{l}\text { Sand } \\
\%\end{array}$ & $\begin{array}{l}\text { Clay } \\
\%\end{array}$ & $\begin{array}{l}\text { Silt } \\
\%\end{array}$ & Text. & $\mathrm{pH}$ & $\begin{array}{l}\text { Organic C } \\
\%\end{array}$ & $\mathrm{Cu}$ & Cd & $\begin{array}{l}\mathrm{Zn} \\
(\mathrm{mg} / \mathrm{kg})\end{array}$ & $\mathbf{P b}$ & $\mathbf{F e}$ \\
\hline \multicolumn{12}{|c|}{ Point 1 (Point of direct discharge) } \\
\hline Atimbo & 88.00 & 1.00 & 11.00 & LS & 6.40 & 7.89 & 7.25 & 0.57 & 52.25 & 2.55 & 1078.18 \\
\hline Ikot Eneobong & 88.00 & 1.00 & 11.00 & LS & 6,85 & 7.99 & 6.95 & 0.45 & 45.15 & 2.95 & 991.64 \\
\hline Nasarawa & 87.00 & 1.00 & 12.00 & LS & 7.35 & 7.30 & 7.60 & 0.45 & 44.30 & 2.35 & 1145.27 \\
\hline Mean & 87.60 & 1.00 & 11.30 & & 6.87 & 7.73 & 7.27 & 0.49 & 47.23 & 2.65 & 1071.69 \\
\hline \multicolumn{12}{|c|}{ Point 2 (20 $\mathrm{m}$ from Point 1$)$} \\
\hline Atimbo & 87.00 & 1.00 & 12.00 & LS & 6.30 & 6.85 & 6.95 & 0.55 & 43.15 & 2.15 & 878.38 \\
\hline Ikot Eneobong & 88.00 & 1.00 & 12.00 & LS & 6.75 & 7.20 & 6.65 & 0.40 & 25.15 & 1.95 & 791.44 \\
\hline Nasarawa & 82.00 & 2.00 & 17.00 & LS & 7.30 & 6.30 & 6.20 & 0.25 & 24.30 & 1.35 & 945.47 \\
\hline $\begin{array}{l}\text { Mean } \\
\text { Point } 3 \text { (Contr }\end{array}$ & 85.30 & 1.30 & 13.66 & & 6.78 & 6.78 & 6.60 & 0.40 & 30.86 & 1.81 & 871.76 \\
\hline Atimbo & 87.00 & 2.00 & 11.00 & LS & 5.00 & 1.10 & 5.54 & 0.24 & 15.80 & 1.54 & 479.90 \\
\hline Ikot Eneobong & 88.00 & 1.00 & 11.00 & LS & 4.80 & 0.90 & 5.38 & 0.30 & 17.00 & 1.61 & 579.99 \\
\hline Nasarawa & 87.00 & 1.00 & 11.00 & LS & 5.20 & 1.00 & 5.43 & 0.36 & 16.10 & 1.65 & 698.86 \\
\hline Mean & 87.30 & 1.30 & 11.00 & & 5.00 & 1.00 & 5.45 & 0.30 & 16.30 & 1.60 & 586.25 \\
\hline SD & & & & & & & 0.83 & 0.12 & 14.58 & 0.53 & 224.99 \\
\hline $\begin{array}{l}\text { Variance } \\
\text { CV }\end{array}$ & & & & & & & $\begin{array}{l}0.69 \\
13.00\end{array}$ & $\begin{array}{l}0.01 \\
31.00\end{array}$ & $\begin{array}{l}212.81 \\
46.00\end{array}$ & $\begin{array}{l}0.28 \\
26.00\end{array}$ & $\begin{array}{l}50621.58 \\
27.00\end{array}$ \\
\hline
\end{tabular}


Amongst the various metals studied, Iron (Fe) yielded the highest values across locations (Figs. 1,2 and 3 ). Values recorded for Iron (Fe) from the study sites ranged between 479.90 - 698.86 $\mathrm{mg} / \mathrm{Kg}, 991.64$ - $1145.27 \mathrm{mg} / \mathrm{Kg}, 791.44-945.47$ $\mathrm{mg} / \mathrm{Kg}$ with means of $586.25 \mathrm{mg} / \mathrm{Kg}, 1071.69$ $\mathrm{mg} / \mathrm{Kg}$, and $871.76 \mathrm{mg} / \mathrm{Kg}$ for the control, Points 1 and 2 (Table 1) respectively. The least mean value $(586.25 \mathrm{mg} / \mathrm{Kg})$ was recorded in the control while the highest mean $(1071.69 \mathrm{mg} / \mathrm{Kg})$ was recorded at the point of direct discharge (Table 1). This research observed a wide spread between data point for $\mathrm{Fe}$ with a coefficient variability of $225.00 \%$. The levels of Fe recorded for the abattoir contaminated soils were slightly higher in values than the control soils but lower than values $(2569.1-4130.0 \mathrm{mg} / \mathrm{Kg})$ recorded by [3] and far below the typical background concentrations of $7000-55.000 \mathrm{mg} / \mathrm{Kg}$ levels outlined by [26].

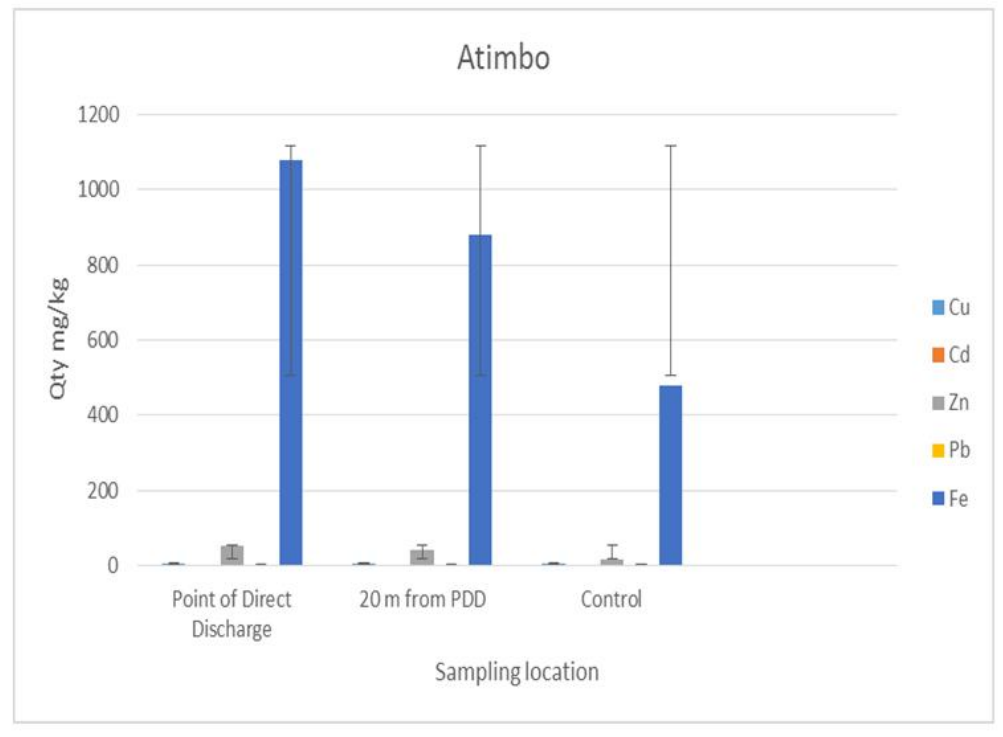

Fig. 1. Mean heavy metals $(\mathrm{mg} / \mathrm{kg})$ in soils contaminated with abattoir effluent in Atnimbo

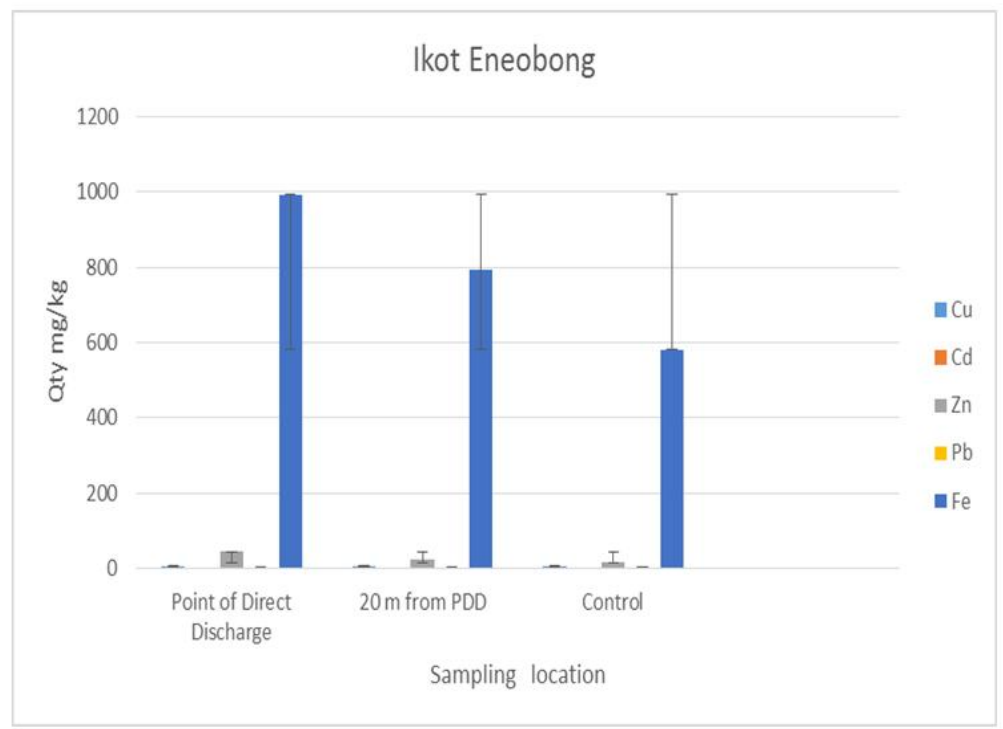

Fig. 2. Mean heavy metals $(\mathrm{mg} / \mathrm{kg})$ in soils contaminated with abattoir effluent in lkot Eneobong 


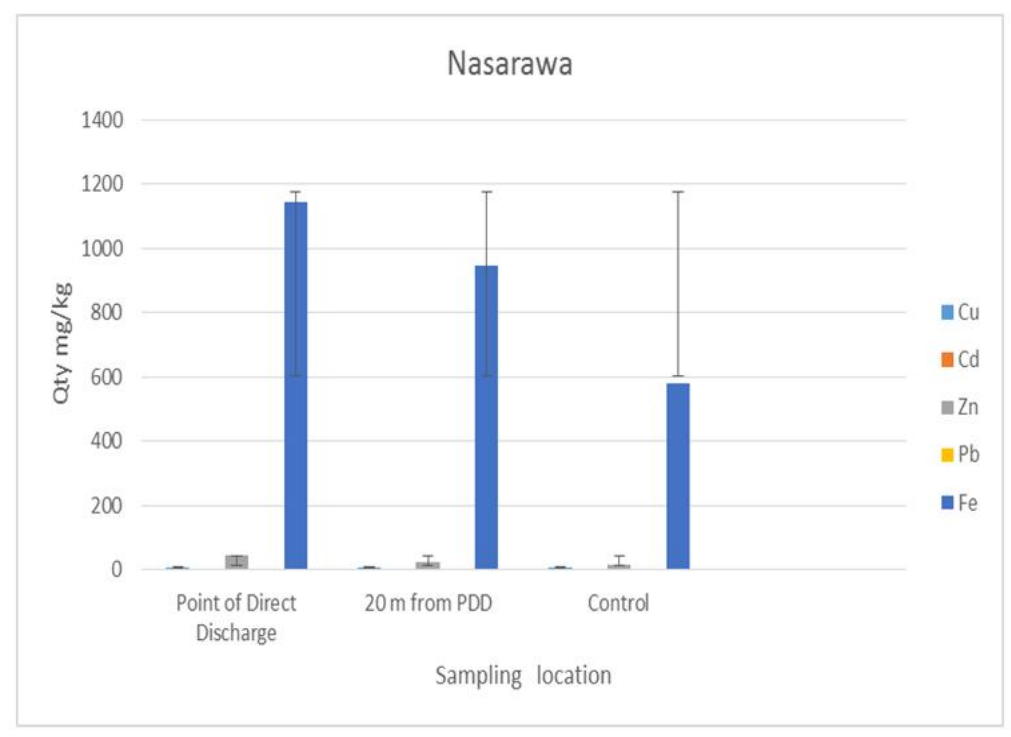

Fig. 3. Mean heavy metals $(\mathrm{mg} / \mathrm{kg})$ in soils contaminated with abattoir effluent in Nasarawa

Generally, the control site recorded the least values for heavy metals when compared with values from the abattoir effluents contaminated soils across the sampling locations (Figs. 1, 2 and 3 ). The analytical determinations portrayed the sequence of heavy metal in the study site as: $\mathrm{Fe}>\mathrm{Zn}>\mathrm{Cu}>\mathrm{Pb}>\mathrm{Cd}$. Heavy metal values recorded in this study for the abattoir contaminated soils in Calabar metropolis are still within the permissible limits probably because the abattoirs are relatively new or as a result of high rate of leaching owing to the sandy nature of the soils and leaching due to high amount of rainfall. The high organic $\mathrm{C}(<6.0 \%)$ observed for the effluents contaminated site (Points 1 and 2) suggests high organic matter content in the soils. This could reduce metal availability due to metal - organic complexation [33].

\subsection{Microbial Analysis}

The results of the percentage occurrence of the microbial isolates are presented in Table 2. The result revealed enrichment in the diversity and population of microorganism in the soils contaminated with abattoir effluents. Although most of the microbes isolated were native to the soils, others were invading organisms attracted by the contaminant or associated with food and beef decay. Amongst the bacterial isolates, Escherichia coli and Bacillus subtilis showed the highest frequency $(15 \%)$ of occurrence and closely followed by Staphylococcus (14\%), Bacillus anthracis (13\%), Bacillus polymyxa and
Klebsiella pneumoniae (8\%). The least frequency of occurrence (4\%) was observed for Staphylococcus epidermides. The prevalence of various species and communities of organisms in the contaminated soils could be attributed to the continuous discharge of the effluents, various stages of decomposition of the effluents/ inclusions (blood, paunch manure, urine, body parts, dung and undigested grains and grasses). The decomposition of the dung explains the high prevalence of Escherichia coli and Streptococcus faecalis in the effluents contaminated soils.

Escherichia coli and Streptococcus faecalis are known to be associated with faecal contaminants while the main microorganisms responsible for fermentation of effluents are Bacillus $s p p$, Staphylococcus spp and Micrococcus spp. Similar, findings of high microbial prevalence have been reported from soil samples contaminated with waste-water from various locations in Nigeria [34,35,36].

Aspergillus niger (30\%) was the most prevalent fungi followed by Fusarium sporotrichoides (20\%) while Mucor pusillus showed the lowest occurrence of $6 \%$ for the abattoir contaminated soils (Table 2). The diverse microbial communities observed in the abattoir effluents contaminated soils could be attributed to the availability of substrates that are easily utilized by the organisms for food and energy source as well as the favourable $\mathrm{pH}$. 
Table 2. Frequency of occurrence of the microbial isolates in abattoir effluents contaminated soils in Calabar Metropolis

\begin{tabular}{|c|c|c|c|c|}
\hline \multirow{2}{*}{$\begin{array}{l}\text { Isolates } \\
\text { 1) Bacteria }\end{array}$} & \multicolumn{2}{|c|}{$\begin{array}{c}\text { Abattoir effluent soils } \\
\text { Mean count (cfu/g) } \\
\text { Frequency of occurrence (\%) }\end{array}$} & \multicolumn{2}{|c|}{$\begin{array}{c}\text { Control soils } \\
\text { Mean count (cfu/g) } \\
\text { Frequency of occurrence (\%) }\end{array}$} \\
\hline & & & & \\
\hline Escherichia coli & $16.2 \times 10^{6}$ & 15 & -- & -- \\
\hline Clostridium spp. & $5.4 \times 10^{6}$ & 5 & -- & -- \\
\hline Bacillus anthracis & $14.1 \times 10^{6}$ & 13 & $4.0 \times 10^{6}$ & 5 \\
\hline Bacillus polymyxa & $8.7 \times 10^{6}$ & 8 & -- & -- \\
\hline Bacillus subtilis & $16.2 \times 10^{6}$ & 15 & $10.4 \times 10^{6}$ & 13 \\
\hline Streptomyces spp & -- & -- & $9.6 \times 10^{6}$ & 12 \\
\hline Streptococcus faecalis & $6.5 \times 10^{6}$ & 6 & -- & -- \\
\hline Salmonella spp & $5.4 \times 10^{6}$ & 5 & -- & -- \\
\hline Staphylococcus aureus & $15.2 \times 10^{6}$ & 14 & -- & -- \\
\hline Staphylococcus epidermides & $4.0 \times 10^{6}$ & 4 & -- & -- \\
\hline Klebsiella pneumoniae & $8.7 \times 10^{6}$ & 8 & $8.0 \times 10^{6}$ & 10 \\
\hline Pseudomonas aeruginosa & $7.6 \times 10^{6}$ & 7 & $8.0 \times 10^{6}$ & 10 \\
\hline Micrococcus spp. & -- & -- & $12.0 \times 10^{6}$ & 15 \\
\hline Arthrobacta spp. & -- & -- & $16.0 \times 10^{6}$ & 20 \\
\hline Nocardia spp. & -- & -- & $12.0 \times 10^{6}$ & 15 \\
\hline Total (CFU) & 108 & 100 & 80 & 100 \\
\hline \multicolumn{5}{|l|}{ 2) Fungi } \\
\hline Aspergillus fumigates & $9.0 \times 10^{4}$ & 10 & -- & -- \\
\hline Aspergillus niger & $27.0 \times 10^{4}$ & 30 & $12.0 \times 10^{4}$ & 20 \\
\hline Aspergillus flavus & $11.0 \times 10^{4}$ & 12 & $11.0 \times 10^{4}$ & 18 \\
\hline Absidia spp. & $7.2 \times 10^{4}$ & 8 & -- & -- \\
\hline Mucor pusillus & $6.3 \times 10^{4}$ & 7 & $4.0 \times 10^{4}$ & 7 \\
\hline Penicillum endrinulatum & $11.5 \times 10^{4}$ & 13 & $9.0 \times 10^{4}$ & 15 \\
\hline Fusarium sporotrichoides & $18.0 \times 10^{4}$ & 20 & $12.0 \times 10^{4}$ & 20 \\
\hline Microsporium spp & -- & -- & $12.0 \times 10^{4}$ & 20 \\
\hline Total (CFU) & 90 & 100 & 60 & 100 \\
\hline
\end{tabular}

\section{CONCLUSION}

This research observed increased heavy metal values at the abattoir environs when compared with the control sites giving a trend of: $\mathrm{Fe}>\mathrm{Zn}>$ $\mathrm{Cu}>\mathrm{Pb}>\mathrm{Cd}$. However, heavy metal values recorded in this study for the abattoir contaminated soils in Calabar metropolis are still within the permissible limits however, precaution needs to be applied as these levels can considerably be increased by accumulation from the continuous discharge of the effluents. The microbial analysis revealed an enrichment of bacterial isolates: Escherichia coli, Clostridium spp., Bacillus anthracis, Bacillus polymyxa, Bacillus subtilis, Streptococcus faecalis, Salmonella spp, Staphylococcus aureus, Staphylococcus epidermides and Klebsiella pneumoniae, Pseudomonas aeruginosa and fungal isolates: Aspergillus fumigates, Aspergillus niger, Aspergillus flavus, Absidia spp., Mucor pusillus, Penicillium spp and
Fusarium spp at the effluents contaminated sites. It is recommended that abattoir effluents be properly channeled into septic tanks to avoid accumulation of heavy metals in plants and surrounding soils as well as prevent the contamination of water bodies and possible disease outbreak, since most of the organisms found there are very harmful to man.

\section{COMPETING INTERESTS}

Authors have declared that no competing interests exist.

\section{REFERENCES}

1. Ediene VF, Iren OB, Idiong MM. Effects of abattoir effluent on the physicochemical properties of surrounding soils in Calabar metropolis. International Journal of Advance Research. 2016;4(8):37-41. 
2. Saskia R, Nico B, Nander VP, Ronny B, Lieven B. Metal exposure and accumulation patterns in free-range cows (Bos taurus) in a contaminated natural area: Influence of spatial and social behavior. Environmental Pollution. 2013; 172:186-199.

3. Yahaya MI, Mohammed S, Abdujahi BK. Seasonal variation of heavy metals concentration in abattoir dumping site soils in Nigeria. J. Appl. Sci. Environ. Manag. 2009;13(4):9-13.

4. Simon T. The effect of increasing rates of nickel and arsenic on the growth of radish and soils microflora. Rostlinna Vyroba (in Czech). 1999;45:421-430.

5. Iram S, Ahmad I, Stuben D. Analysis of mines and contaminated agricultural soils samples for fungal diversity and tolerance to heavy metals. Pakistan Journal of Botany. 2009;41(2):885-895.

6. Trueby $P$. Impact of heavy metals on forest trees from mining areas. In: International Conference on Mining and the Environment. Sudbury, Ontario, Canada; 2003.

7. Nannipieri P, Badalucco L, Pietramellara $\mathrm{G}$. Measurement in assessing the risk of chemicals to the soils ecosystem. In: Zellkoff JT. (ed.). Ecotoxicology; Responses, biomarkers and risk assessment. OECD Workshop. SOS Publ. Fair Haven, New York. 1997;507-534.

8. Habashi F. Environmental issues in the metallurgical industry. Progress and problems, environmental issues and waste management in energy and mineral production Balkama, Rothendam. 1992; 1143-1153.

9. Garbarino JR, Hayers $H$, Roth D, Antweider $\mathrm{R}$, Brinton $\mathrm{T}$, Taylor $\mathrm{H}$. Contaminations in the Mississippi River, U.S. Geological Survey Circular 1133, Virginia; 1995.

10. Horsfall MN, Spiff AL. Speciation of heavy metals in intertidal sediments of the Okirika River System (Nigeria), Bull. Chem. Soc. Ethiopia. 1999;13(1):1-9.

11. Peplow D. Environmental impacts of mining in Eastern Washington, center for water and watershed studies fact sheet. University of Washington; 1999.

12. Federal Airport Authority of Nigeria (FAN). Meteorological data. Unpublished, Calabar, Nigeria; 2015.
13. Akpan-Idiok AU. Physicochemical properties, degradation rate and vulnerability potential of soils formed on coastal plain sands in southeast, Nigeria. International Journal of Agriculture. 2012;7(7):358-366.

14. Iren OB, Ediene VF. Effect of spent engine oil discharge on soil properties in selected automobile workshop in Calabar, Cross River State, Nigeria. International Journal of Innovative Science, Engineering \& Technology. 2017;4(2):391-401.

15. Zuberer DA. Recovery and enumeration and viable bacteria. Method of soil analysis. Part 2 microbiological and biochemical properties. Soil Science Society of America book Series; 1994.

16. Srikanth P, Somasekhar SA, Kanthi GK, Raghu BK. Analysis of heavy metals by using atomic absorption spectro-scopy from the samples taken around Visakhapatnam. International Journal of Environment, Ecology, Family and Urban Studies. 2013;3(1):127-132.

17. Alef K. Nutrients, sterilization, aerobic and anaerobic culture techniques in applied soil microbiology and biochemistry. Academic Press Limited. 1995;124(4):110-130.

18. Dennis P. Flamentous fungi In: 571 Mikelson (ed.), Methods of soil analysis, part 2, microbiological and biochemical properties. Washington DC: Soil Science Society of America; 1994.

19. Weaver RA, Peter GH. Method of soil analysis part 2 microbiological and biochemical properties. Soil Science Society of America Book Series; 1994.

20. Harrigan WF, Mc. Cance ME. Laboratory methods in food and dairy microbiology $\left(8^{\text {th }}\right.$ Ed.) London: Academic Press; 1990.

21. Cheesbrough M. District laboratory practice in tropical countries. Part 2. Low price edition. Cambridge University Press, London; 2006.

22. Bergey's Manual of Determinative Bacteriology. $9^{\text {th }}$ edition, Holt JD, (Ed.), Williams Wilkins CO. Baltimore; 1994.

23. Barnett HL, Hunter BB. Illustrated genera of imperfecti fungi, $3^{\text {rd }}$ edition, Burgess Publishing Company, Minnesota, USA; 1972.

24. Fuentes $A$, Lloren $M$, Saez J, Soler A, Aguilar MI, Ortuno JF, Meseguer VF. Simple and sequential extractions of heavy Metals from different sewage sludge. Chemosphere. 2004;54:1039-1047. 
Available:http://dx.doi.org/10.1016/j.chemo sphere.2003.10.029

25. Lewis SME, Donkin MH. De pledge Hsp70 expression in Enteromorpha intestinalis (Chlorophyta) exposed to environmental stressors. Aquatic Toxicology. 2001;51: 277-291.

26. Nangia SB. Soil pollution. Ashish Publishing House. New Delhi-110026; 1991.

27. Kabata- Pendias A, Pendias H. Trace elements in soil \& plants. $3^{\text {rd }} \mathrm{Edn}-\mathrm{CRC}$ Press Inc; Boca Raton, FL - USA; 2000. ISBN- 1319780849315756

28. Alloway BJ, Alloway B. Heavy metals in soil. Blackie, Glasgow; 1995.

29. Salt DES, Rauser WE. MgATP-dependent transport of phytochelatins across the tonoplast of oat roots. Plant Physiology. 1995;107:1293-1301.

30. Choi JM, Pak CH, Lee CW. Micronutrient toxicity in French marigold. Journal of Plant Nutrition. 1996;19:901-916.

31. Ebbs SD, Kochian LV. Toxicity of zinc and copper to Brassica species: Implications for phytoremediation. Journal of Environmental Quality. 1997;26:776-781.

32. Fontes RLS, Cox FR. Zinc toxicity in soybean grown at high iron concentration in nutrient solutiom. Journal of Plant Nutrition. 1988;21:1723-1730.

33. Sharma $P$, Dubey RS. Lead toxicity in plants Brazilian. Journal of Plant Physiology. 2005;17:35-52.

34. Gupta AK. Sinha S. Phytoextraction Capacity of the Plants Growing on Tannery Sludge Dumping Sites. Bioresource Technology. 2007;98:1788-1794.

Available:http://dx.doi.org/10.1016/j.biortec h.2006.06.028

35. Atlas RM, Bartha R. Microbial ecology: Fundamentals and applications, Benjamin/Cummings Publishing Company Inc., India; 2007.

36. Rabah AB, Oyeleke SB, Manga SB, Hassan IG, Ijah UJ. Microbiological and physico-chemical assessment of soils contaminated with abattoir effluents in Sokoto metropolis, Nigeria. Science World Journal. 2010;5(3):1-4.

(c) 2017 Ediene and Iren; This is an Open Access article distributed under the terms of the Creative Commons Attribution License (http://creativecommons.org/licenses/by/4.0), which permits unrestricted use, distribution, and reproduction in any medium, provided the original work is properly cited.

Peer-review history:

The peer review history for this paper can be accessed here: http://sciencedomain.org/review-history/19111 